\title{
Effect of Covid-19 Pandemic on Performance of Women Owned Micro, Small and Medium Enterprises in Kenya
}

\author{
Salome K. Kaberia ${ }^{1}$, \& Stephen M. A. Muathe ${ }^{1}$ \\ ${ }^{1}$ School of Business, Kenyatta University, Kenya \\ Correspondence: Salome K. Kaberia, School of Business, Kenyatta University, Kenya.
}

Received: September 17, 2020

Accepted: November 13, $2020 \quad$ Available online: November 24, 2020

doi:10.11114/ijsss.v9i1.5089

URL: https://doi.org/10.11114/ijsss.v9i1.5089

\begin{abstract}
The year 2020 marks the silver jubilee of the Beijing Platform for Action, and was expected to be a moment to celebrate the milestones made in enhancing gender parity and opportunities. However, the effects of COVID-19 pandemic threaten to erode the minimal gains achieved this far. The pandemic, initially a health hazard, fast mutated to a twin-menace that would threaten both lives and livelihoods. Global stock markets plunged in value by about US\$6 trillion in less than a week (24th to 28th February 2020), according to S \& P Dow Jones Indices; with many yet to recover. The pandemic decelerated Kenya's projected GDP growth; the Central Bank of Kenya revised its estimate for 2020 from the initial $6.2 \%$ to 3.4\%. Most affected were Micro, Small and Medium Enterprises; due to limited resources unable to withstand prolonged uncertainty and multi-faceted restrictions, as demanded of them by the pandemic. Key among the ventures threatened with extinction are women owned Micro, Small and Medium Enterprises that faced numerous pre-pandemic challenges. The inevitable priority shift for women entrepreneurs, diversion of business funds, sharp decline in demand and supply of commodities, and costly production, all stifled the mostly informal firms. Theories supporting this magnitude of impact are limited too; with the closest being resource dependency theory, structural inertia theory and real options theory. As uncertain as the viral spread is its ultimate impact on businesses and economies. This study uses available secondary multi-disciplinary resources; research papers, case studies, stakeholder reports and other online sources. Findings are that women owned businesses are disproportionately affected by the pandemic. The study recommends targeted policy, research and resource interventions to help small ventures prepare for recurrence of such contagions through resurgence of the same or new pandemics in future.
\end{abstract}

Keywords: pandemic, women owned businesses, micro, small and medium enterprises

\section{Introduction}

Micro, Small and Medium Enterprises (MSMEs) play a significant and indispensable role in the economic development of a country. They generate varied sources of income, create employment, enhance innovation and competition, provide opportunity for upskilling, and ultimately help improve living standards. These in turn promote entrepreneurship, build an industrial base at diverse levels and build resilience of economies (Anyanga \& Nyamita, 2016; KNBS, 2016; Miles, Lehman \& Fillis, 2017). Success of any economy depends on the success of businesses within it; MSMEs thus form the backbone of most economies (Ndiaye, Razak, Nagayev \& Ng, 2018).

Globally, the pivotal role of MSMEs has been demonstrated through their contribution to the gross domestic product (GDP) of many economies. In economies such as China and Japan, small and medium enterprises (SME) contribute 60\%, in the USA they generate $65 \%$ and in UAE they contribute $52 \%$ to the respective GDPs. (Kawira, Mukulu, \& Odhiambo, 2019).

According to the International Finance Corporation (IFC, 2016), one in every three registered ventures are owned by women. If eighty percent of employments globally are in SMEs, and these are disproportionately owned and run by women, this is therefore a critical mass that deserves attention and deliberate efforts to improve it by all stakeholders. The ILO further approximates that 50 percent of women's productive potential remains underutilized as compared to 22 percent of men's potential.

Regionally, Small and Medium Enterprises (SMEs) encompass over 90\% of African business enterprises and generate over 50\% of African employment opportunities and GDP. Moreover, there are about 400 million MSMEs in developing countries, with most of them being informal. Africa has the highest rates of female entrepreneurship, with women bearing 
half of non-farm business ownership (International Development Research Centre, IDRC, 2016).

In Ghana, the MSME sector accounts for $92 \%$ of businesses, offer about $70 \%$ of industrial employment and contributes way over 50\% of the country's GDP (Dzisi \& Ofusu, 2014; Wega, 2018). In Nigeria, the contributions of Small and medium scale business as a creator of employment is widely recognized with over $80 \%$ of firms in the manufacturing sector being SMES (Kawira, et. al., 2019). In South Africa, SMEs contribute about $56 \%$ of private sector employment and $36 \%$ of GDP (Neneh \& Zyl, 2012).

In Kenya, as in many other growing economies, MSMEs are central to the development of the economy. They comprise about $80 \%$ of all Kenyan businesses (7.4 million MSMEs), jointly employ approximately 14.9 million people (78\% of labor force) and account for a third of Kenya's GDP (Krishnan, Were, and Te Velde 2019). This is despite over 85\% of these ventures being unlicensed thus forming part of the informal sector popularly known as jua kali sector (KNBS, 2016). The MSME sector not only provides goods and services but is also a key driver in stimulating competition and innovation while enhancing the enterprise culture that is critical for economic advancement, industrialization and transformation (KIPPRA, 2013; RoK, 2015). KNBS (2016) emphasized the critical role of MSMEs in Kenya's industrialization strategy; more so in generation of employment and income opportunities for the majority of people.

Small and medium enterprises (SMEs) face various small and large internal as well as external risks. While they are better placed to handle most of the internal risks through risk management and mitigation methods, they are often more susceptible to external risks which tend to be beyond their control and ability to manage, and unforeseen (Asgary, Ozdemir \& Özyürek, 2020). Despite the recognition of MSMEs in the economic development, 70 percent of women owned MSMEs in developing nations are underserved or not served at all by financial institutions. Women owned businesses yield on average lower sales and are mainly huddled in flooded and low-profit segments as well as markets, (IFC, 2016).

\subsection{The COVID-19 Outbreak}

The outbreak that started in Wuhan, China, in December 2019, initially seemed like a problem for China only, but soon spread out so fast that WHO declared it a global pandemic on 11th March 2020. The pandemic soon impacted on the political, social, religious, economic and financial structures of the entire world; topmost global economies notwithstanding. As at early July 2020, there were over 11 million confirmed cases of COVID-19 worldwide, and over 500,000 deaths resulting from this novel virus (World Health Organization, WHO, 2020; McKinsey \& Company, 2020).

It is against this backdrop that economies worldwide found themselves grappling with a crisis that not even the most prepared of governments and businesses could adequately handle; the novel contagion. "It is the worst global crisis since the Second World War" (ILO, 2020). It could only get much worse for the already struggling sectors such as women owned businesses (McKinsey \& Company, 2020).

The United Nations Conference on Trade and Development (UNCTAD, 2020), posits that a deceleration of the worldwide annual economic growth less than $2.5 \%$ would often be viewed as the recessionary verge for the worldwide economy. UNCTAD further approximates that $1 \%$ decline in the global economic growth leads to income losses of 900 billion US dollars. The global cost of COVID-19, is, thus, likely to wipe off from the global economy approximately 2 trillion US dollars. Loss of jobs between February and March 2020 is estimated at 24.3 million globally. The impact of such losses will deal a real blow particularly on developing economies that greatly rely on investment and trade, foreign expertise, tourism and financial support from the more established countries.

The UN Economic Commission for Africa approximates that Africa's growth will drop by $1.4 \%$ from $3.2 \%$ to $1.8 \%$ as a result of COVID-19. The decline is broadly due to the unprecedented disruption of global supply chains as well as the dip in oil prices likely to cost about US\$65 billion in export revenues. Owing to the uncertainty of the disease and possibly in search of their own safety, the Investors, too, quickly fled the emerging markets.

Kenya confirmed her $1^{\text {st }}$ COVID-19 patient on $13^{\text {th }}$ March 2020 and since then, the numbers have been steadily rising. Anxiety seemed to spread faster than the disease; weeks before Kenya could confirm her first case, more than $61 \%$ of the businesses had already reported financial losses. With increasing societal anxiety and fear of visiting hospitals by most people, women entrepreneurs had to deal with the decline in business performance, coupled with increasing numbers of family members that needed unpaid care either due to illness or indefinite closure of schools.

The GOK subsequently instituted strict measures to control the spread of this dreaded disease, such as limitation of movement into and out of the affected Counties, work from home directive, closure of bars and restaurants, cessation of public gatherings, $7 \mathrm{pm}$ curfew, and the ban on local and international air travel. These measures led to loss of income and reduced operating hours, with some firms, particularly MSMEs that have unsteady cash flows, being forced to lay off workers or send them on unpaid leave indefinitely. The uncertainty of the situation and how long it may last has led to a decrease in proceeds; adversely affecting aggregate demand and supply. 
While there were government initiatives to help cushion the economy such as the Central Bank of Kenya lowering the base interest rates and tax reliefs among others, these measures largely favored people in formal employment - most women entrepreneurs subsist within informal employment and have unsteady flow of cash, with many being daily income earners who would not gain from the relief of tax. The actual impact of COVID-19 on Small and Medium Enterprises and more so women-owned MSMEs may not be fully appreciated now, but indicators are that there are many small ventures that may never recover. There is consensus, nonetheless, that the pandemic can only aggravate an already dire situation.

It is worth noting that Kenya was also dealing with a locust invasion as well as flooding and landslides in some parts, whose impact has not been fully assessed but is expected to impact on agricultural output during the harvest season. From a very conservative perspective, women consist about 50 percent of the agricultural labor force in sub-Saharan Africa, an increase from about 45 percent in 1980. The averages in Africa range from slightly above 40 percent in Southern Africa to about 50 percent in Eastern Africa, (FAO, 2011).

\subsection{Impact on Micro, Small and Medium Enterprises}

The influence and contribution of MSME's to the Kenyan economy and development remains invaluable (Muathe, Wawire \& Ofafa, 2013; Ngugi, 2014). MSMEs are not only providers of goods and services, they cultivate innovation and competition, generate employment opportunities, improve livelihoods and ultimately alleviate poverty. Kenya's economic blueprint towards industrialization and quality life for all citizens, the Vision 2030, depicts MSMEs as key development drivers (Kenya National Bureau of Statistics, KNBS, 2016).

Impact of such crises, therefore, is a direct hit on women-owned ventures who rely on farming to feed their families, sell produce as a means of livelihood, or both. Further research will thus help to ascertain what would have had more impact on agricultural output; COVID-19 or the locust menace.

Towards realization of Vision 2030, the Government of Kenya, (GoK), and other stakeholders have initiated and implemented various reforms and incentive programs. These are aimed at catalyzing the development of growth oriented Micro and Small Enterprises (MSEs) that should graduate into Medium and large enterprises capable of contributing to the industrialization goal. Among these are Sessional Paper No. 1 (1986) on Economic Management for Renewed Growth, Sessional Paper No 2 on Small Enterprises and Jua Kali Development (1992) and Sessional Paper No. 2 (2005) on Development MSE for Wealth and Employment Creation for Poverty Reduction (KNBS, 2016).

Legislative and special programs include Micro-Finance Act (2006) and MSE Act No. 55 (2012), Assistance to MSE Program (ASMEP, 2007) and MSME Competitiveness Project. GoK, through the Central Bank of Kenya (CBK), further set up revolving funds for special segment MSMEs, e.g. Women and Youth Fund. In response to the contagion, GoK introduced stimulus packages with tax breaks aimed at cushioning the businesses (CBK, 2020).

Women entrepreneurs have further sought to overcome their unique challenges through social groups that provide training and table banking services, joining segment peer groups such as women in business forums organized by learning institutions (e.g. Women in Leadership by Strathmore Business School), International Trade Centre initiatives such as SheTradesKE that aim to empower more women to trade across borders, and initiatives driven by financial institutions such as Kenya Women Finance Trust. Multinationals too such as Absa Bank, while hosting the Women In Business forum in early 2020, unveiled a Kes. 10 billion fund to advance credit to women-owned small and medium businesses over a five-year period (ITC, 2020).

Despite these concerted efforts by the government and complementary initiatives by stakeholders as well as women entrepreneurs themselves, the performance of women owned enterprises remains wanting, more so during and after the contagion. The ongoing pandemic threatens to wipe out all gains made in the past decades, thus exacerbating an already bad situation (World Bank, 2020). According to a World Bank and OECD research (2020), women owned enterprises globally have a 5.9 percent higher risk of closure than male-owned businesses, when controlling for region. Further, the research showed that the ability of women owned businesses in Africa to generate revenue is disproportionately affected by the pandemic compared to their male colleagues.

The contagion has triggered the first recession in Sub-Saharan Africa in 25 years, with growth projection ranging between -2.1 and -5.1, far from a modest $2.4 \%$ in 2019 (World Bank, 2020). It has been noted that COVID-19 government stimulus packages and policy tools to SMEs are largely beneficial to the formal sectors (FinMark Trust, 2020).

Consequently, female owned businesses in the informal and service sectors are much more likely to withdraw from the market due to decline in demand (Women Entrepreneurs Finance Initiative, We-Fi, 2020). In Uganda, for instance, research showed that $61 \%$ of women owned enterprises had no income compared to $22 \%$ of men owned ventures. South Africa and Rwanda mirrored these trends. Despite the easing of lockdown measures, female entrepreneurs will encounter increased operational costs due to the conditions of the new normal (distanced sitting in restaurants, sanitization costs among others), and the reduced spending power of consumers with limited or no income (FinMark Trust, 2020). 
Women entrepreneurs are predominantly present in consumer facing segments that have experienced extended closures namely cafes, education and child-care facilities, personal grooming and fitness services. Owing to this, women owned businesses will suffer long after the lockdown eases compared to their male counterparts (World Bank, 2020).

This study therefore seeks to nudge all stakeholders to pay closer attention to this special category of women owned MSMEs that is so critical yet so fragile due to pre-existing inequalities. Women owned MSMEs have every indicator that they will be the hardest hit by the impact of this pandemic, but they also have the promise of being the backbone of recovery across societies. Every policy response that takes cognizance of this fact will be the more impactful for it (World Bank, 2020).

\section{Review of Literature}

This section seeks to outline the theoretical models applied as well as the empirical literature reviewed in line with the objective of the study.

\subsection{Theoretical Review}

Due to the novelty of this pandemic and its effects, there seems to be a limited theoretical backing for businesses during such uncertainties. Craighead et. al., (2020), proposes that pandemics are qualitatively very different from typical business disruptions; hence scholars must sharpen their theoretical tools in line with the new theoretical demands made of them and the survival of MSMEs. The proposed theories, though limited in view of the pandemic's impact, are Resource Dependency theory, Structural Inertia theory and Real Options theory.

Resource dependence theory (RDT) argues that businesses depend on others within their environment for access to critical inputs such as materials, labor, and cash (Pfeffer \& Salancik, 1978). Dependence thus generates uncertainty as the external parties may fail the firm for various reasons. Ventures react by putting in place strategies and structures that may decrease or eliminate their dependence on external parties. While the strategies may have proved workable for normal modes of operation and typical disruptions, both the structures and strategies may not handle the supersonic speed and nature of pandemics.

Additionally, while structures in place may be successful within typical short-term disruptions, they may not have any merit during pandemics that come with dynamic dependencies, (Craighead et. al., 2020). Evidently, the extreme shifts in supply and demand that characterized the COVID-19 pandemic were enough to alter all equations; more so for the MSMEs.

Structural Inertia theory, arising through evolution of population ecology thinking, portends that structural inertia (natural selection beyond the firm's control) explains why some businesses cannot adjust to changing conditions (Hannan \& Freeman, 1984). Ordinarily, women owned MSMEs tend to fail more than men owned and larger firms due to resource limitations among other factors (Hannan \& Freeman, 1984). In times of strife, the risk is amplified because the women owned MSMEs do not operate on a level ground with their counterparts, and they often lack the resources requisite for the level of 'transiliency' (resilience during transition) needed for survival (Craighead et. al., 2020).

Real options theory (Myers, 1977), has a focal point on how managers can make better decisions when faced with uncertainty; by creating real option for themselves in which they have an opportunity rather than an obligation to take daring decisions. Undoubtedly, pandemics such as COVID-19 have created the highest level of uncertainty in modern history, thus leaving the entrepreneurs in precarious situations.

Some managers quickly exploited the opportunity by swiftly changing their modes of operations, e.g. restaurants started offering take away services only, supermarkets started offering deliveries at no cost upon customers placing online orders - thus the flexible businesses adopted a new normal which is likely to progress beyond the pandemic. Some businesses and economies too, have exploited the situation to gain a competitive advantage; such as China that has seized the opportunity to acquire European based infrastructure as well as technology (Rapoza, 2020). However, most small businesses make very minimal profit margins and could not afford this kind of incentives, pushing them further into unfair competition as the larger corporates took their market share.

\subsection{Empirical Review}

COVID-19 pandemic has proven to be one of the largest disruptions in contemporary history; having spread to over 200 countries and regions around the world and subsequently triggered the worst economic depression since the Great Depression (International Monetary Fund, 2020). Governments and businesses alike initially went into panic mode, torn between choosing lives or livelihoods, which seemed mutually exclusive (McKinsey \& Company, 2020). Most governments chose the former and put in place measures and restrictions intended to curb the spread of the virus. Demands were made on the businesses that required swift decisioning with little or no cushioning or fallback options; the situation was dire. 
Gilbert, Pullano, Pinotti, et al., (2020) considered two indicators as a measure of the capability of countries to detect and respond to cases, and by extension the economy's vulnerability; namely preparedness and vulnerability. Their findings indicate that Egypt, Algeria, and South Africa exhibited the highest importation risk, and a moderate to high capacity to respond to outbreaks. Nigeria, Ethiopia, Sudan, Angola, Tanzania, Ghana, and Kenya showed moderate risk with variable capacity and high vulnerability.

Owing to the fear and anxiety instilled by this novel virus, almost everything including academic research almost seemed to be at a standstill for a short while when the pandemic hit the world. The actual impact of the pandemic is yet to be determined; hence current studies have only considered short durations during the pandemic (World Bank, 2020). Further studies post the pandemic will be more precise and detailed in terms of the impact on women owned businesses. It is however projected that most of the women owned MSMEs may not survive the pandemic (McKinsey, 2020).

Micro, Small and Medium Enterprises have been hardest hit by the effects of this pandemic - from the curfews, social distancing, to the supply chain disruptions that saw them compelled to close much earlier, shut down (entertainment and personal service sectors), and contend with shortage of much needed supplies (World Bank, 2020). Women-owned businesses suffered a bigger blow as the stay-home campaigns became the 'only' solution at hand; the women entrepreneurs had to revert to their first role - unpaid home care, while businesses took a distant last in the list of priorities. Business resources were diverted in a bid to stockpile for the families, self-medicate at home for fear of going to hospitals for all other ailments, and supporting the struggling extended families (United Nations, 2020).

Bartika, Bertrand, Cullenc, Glaeserd, Lucac, and Stanton, (2020), took a survey of over 5,800 MSMEs operating in the United States of America. The survey was administered in collaboration with Alignable, a network-based platform that focuses on the MSME ecosystem. The findings were that small businesses were financially very fragile, with most having less than one month's worth of expenses at hand. Barely few weeks into the pandemic, 43 of small businesses had temporarily closed; risk of permanent closure was negatively related to the length of the catastrophe. If despite the administrative support of small businesses in America the impact was so severe weeks into the crisis, how much worse for developing economies like Kenya where small business operate with minimal capital, are heavily dependent on routine transactions and quite a limited number of local customers (Williams \& Schaefer, 2020).

The Korean Federation of MSMEs studied the performance of MSMEs in light of the pandemic. Of 407 surveyed SMEs, 42.1per cent could continue operating no more than three months and 70.1 percent no more than six months under the quarantine circumstances (OECD, 2020). The federation further studied the impact of supply chain disruptions on MSMEs due to covid-related restrictions. Of the 191 businesses surveyed, 71.8 percent anticipated disruptions, with over 50 percent expressing inability to meet delivery timelines due to factory closures in China (OECD, 2020).

A team from Enterprise Survey for Innovation and Entrepreneurship in China (ESIEC) partnered with Peking University to do a follow up survey of 2,349 earlier sampled MSMEs in seven provinces in China. Background information of the businesses had been collected in an earlier study between 2017 and 2019. Findings indicated that 80\% of surveyed enterprises were yet to resume business operations by mid-February, and $10 \%$ were not able to determine timeframes for reopening (Dai, Hu, \& Zhang, 2020). The pandemic, having started in China and adversely impacted China's MSMEs despite the conducive small business environment in China, other countries that heavily rely on China for trade, supply of raw materials and products, such as Kenya, are bound to receive the ripple effect of China's economic situation

Shafi, Riu and Ren (2020) studied the impact of Covid19 on MSMEs in Pakistan. They applied an exploratory design but also sought to validate the data with empirical primary data collected from 17 MSMEs operating in Pakistan. Owing to need for social distancing and restrictions on face to face meetings, questionnaires were administered online through social media. Findings revealed that most of the enterprises were severely affected, with 38 experiencing a severe business impact between $91 \%$ and $100 \%$. The five major challenges identified were financial access, disruptions in supply chain, declines in demand and decrease in sales and profits.

While the study gives an indication of the weighty impact, the very fact that the participating businesses had an online presence implies that the MSME environment in Pakistan is likely different from the Kenyan MSME environment given that most MSMEs in Kenya operate informally. The brunt of the life saving measures cut across sectors and industries with travel bans affecting the aviation industry, cancellation of sporting events, and social gathering embargos that halted the entertainment industries. (Horowit, 2020; Elliot, 2020).

It is postulated that the impact of COVID-19 on African nations will be less from health-related concerns than the economic shock, business disruption and Government response to the predicament, (United Nations, 2020). Owing to nature and nurture factors, women in Africa are often more likely than men to venture into entrepreneurship; comprising $58 \%$ of Africa's self-employed population, (World Bank, 2020).

Findings from Senegal reveal that over $60 \%$ of women-led MSMEs in the trade sector have temporarily or permanently 
shut down due to Covid-19, as opposed to only $46 \%$ of male-owned businesses. The findings are echoed in the Small and Growing Businesses (SGBs) within the Aspen Network of Development Entrepreneurs (ANDE) global network; through a recent Dalberg-supported survey which revealed that a larger number of women-led businesses $(46 \%)$ have temporarily shut down as a result of Covid-19 compared to male-led businesses (39\%), (Dalberg, 2020).

Wenham, Smith, and Morgan (2020) posit that pandemics impact women entrepreneurs in numerous ways ranging from an increase in childcare responsibilities, impacting their participation in work outside the home and committing their business funds to meet the family obligations. Travel restrictions too tend to affect women more than men; especially the informal sector women-led businesses that must source their goods everyday (Kenya's mama mboga). Korkoya and Wreh (2015) found that $70 \%$ of small-scale traders in Liberia are women, thus domestic travel restrictions during the Ebola outbreak disproportionately affected women.

During the Ebola outbreak in Sierra Leone, it was reported that the reduction in life-saving health service translated to a 3,600 additional maternal, neonatal and stillbirth deaths in the year 2014-15 (Sochas, Channon, \& Nam 2017). It has been noted that when women have less decision-making power than men, be it in households, business or government, the women's needs are unlikely to be unmet; more-so during a pandemic. Crises further pose a grave threat to women's engagement in economic activities; be it employment or self-employment.

Lakuma and Sunday, (2020), who studied the impact of COVID-19 on MSMEs in Uganda, used questionnaires to 147 micro, small, medium and large businesses. The questions focused on business risk indicators namely business activity, access to raw material, changes in demand, operating expenses, productivity and credit and liquidity constraints, all subjected to a Likert scale. The finding was that micro and small enterprises suffered a steeper decline in business activity in comparison to medium and larger businesses, with majority of small and medium enterprises predicting total shutdown within one to three months of covid-related restrictions. The study did not consider the gender aspect of the impact among entrepreneurs.

Further, despite neighboring Kenya, the impact of this pandemic in Uganda has been relatively less, if the reported cases are anything to go by; Uganda was still at barely 1000 confirmed cases while Kenya was already reporting over 25,000 cases. As such the impact on the businesses may not necessarily be comparable either.

\subsubsection{Impact on Kenyan Women Owned Enterprises}

According to Ozili and Arun (2020), the health crisis stifled the global economy in two major ways namely social distancing in a bid to curb the spread of this virus which led to shutdown of financial markets, businesses and all social gathering, and the intensified uncertainty around the hasty rate of spread of the virus, which led to hibernation among consumers and investors. Both demand and supply were thus adversely affected. Kenya ranks among the top ten most vulnerable economies to COVID-19, largely due to her close interrelations with China, and given that Kenya, like most other developing nations, is not well prepared to handle the impact of a health pandemic of such magnitude (Raga \& Velde, 2020).

The 2019 Kenya Population and Housing Census revealed that about 19.5 million are poor in Kenya. Of these, 14 million, 1.3 million and 4.2 million were in rural areas, peri-urban / core-urban and informal settlements, respectively (UNDP, 2020). Impact is higher in the urban areas as compared to rural areas; women owned businesses within the major cities are more affected by COVID-19 as compared to the rural areas. Impact in the rural areas is less direct; largely resulting from the disruption of the supply chain and fluctuating operations in Mombasa and Nairobi (United Nations, 2020).

Continued challenges in obtaining capital for growth among women owned businesses will further be compounded by the effects of the pandemic, as most women owned ventures will not have favorable business performance record to qualify for these loans. For an economy like Kenya where women owned ventures are mostly small and informal, the number of women entrepreneurs accessing funding over the years has been negligible. This is evident from the below excerpt that speaks to the funding trends. 
Table 1. Loan disbursement trends

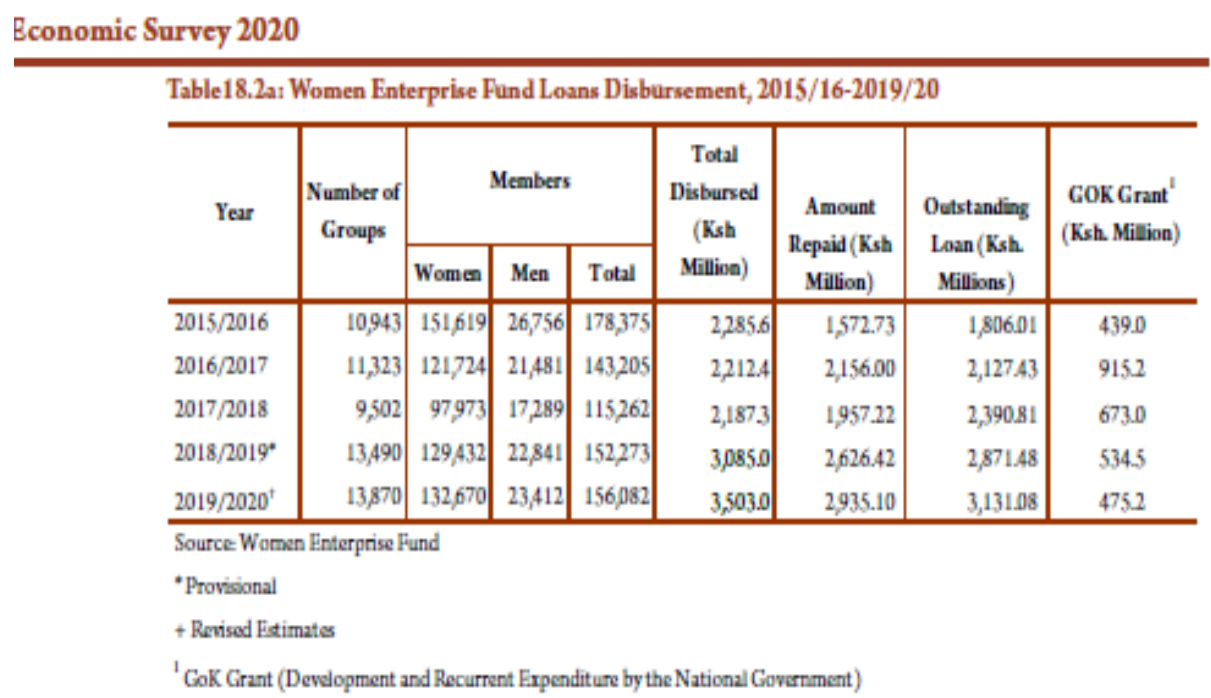

Source: KNBS, Kenya Economic Survey 2020

There is need, therefore, for deliberate efforts to support women owned ventures towards business expansion and increase efficiencies towards growth.

Within the major towns, the impact has been immense due to the imposed preventive measures that led to interruption on both the demand and supply chains, and aggravated customer aversion behavior. This is largely because women are more involved in the informal businesses such as hairdressing, sale of groceries, laundry and home cleaning services etc., most of which are the exact opposite of social distancing.

The UNDP (2020) report further indicates that poverty affects women more than men. While the daily infection and mortality rates of COVID-19 seemed to favor women (Wenham, Smith \& Morgan, 2020), the impact of this contagion is likely to excessively affect the female gender in Kenya. According to the Kenya Integrated Household Survey (KIHBS, 2015/2016), about $30.2 \%$ of female headed households were poor compared to $26.0 \%$ households headed by men. It thus follows, that the COVID-19 pandemic would probably aggravate poverty among these females headed households.

The female labor involvement rate of $75.9 \%$ is lower than the male labor involvement rate of $79.2 \%$ (KNBS, 2018). In Kenya, women make up $75 \%$ of health sector labor force, thus increasing the probability that they will be more affected by the pandemic than their male counterparts - directly and indirectly. Women tend to own and lead smaller businesses, often unlicensed, and concentrated in informal sectors and low value-added sectors. These combined factors often limit the women entrepreneur's access to formal funding and social protection; both aggravated by COVID-19, (World Bank, 2020).

UNDP's Gender Social Norms Index revealed that globally, 50\% of men concurred that men ought to be accorded more rights to employment and economic activities compared to women; more so during shortage and crises. Post the crisis, the Ebola virus trend revealed that men's economic activity returned to pre-crisis levels shortly after interventions were put in place (UNDP, 2020). For women, however, the negative impact on economic activity, security and livelihoods took much longer.

According to the Second Quarter Quarterly Gross Domestic Product Report (KNBS, 2020), the economy shrunk by 5.7 percent; the worst dip in about two decades, and which was attributed to covid-19 related measures in place during the quarter under review. Seeing that these measures will persist through the rest of this year, projection of the trend does not promise much change. 


\section{Trends in Q2 GDP growth rates (\%)}

Kenya's economy contracted by $5.7 \%$ in 202020

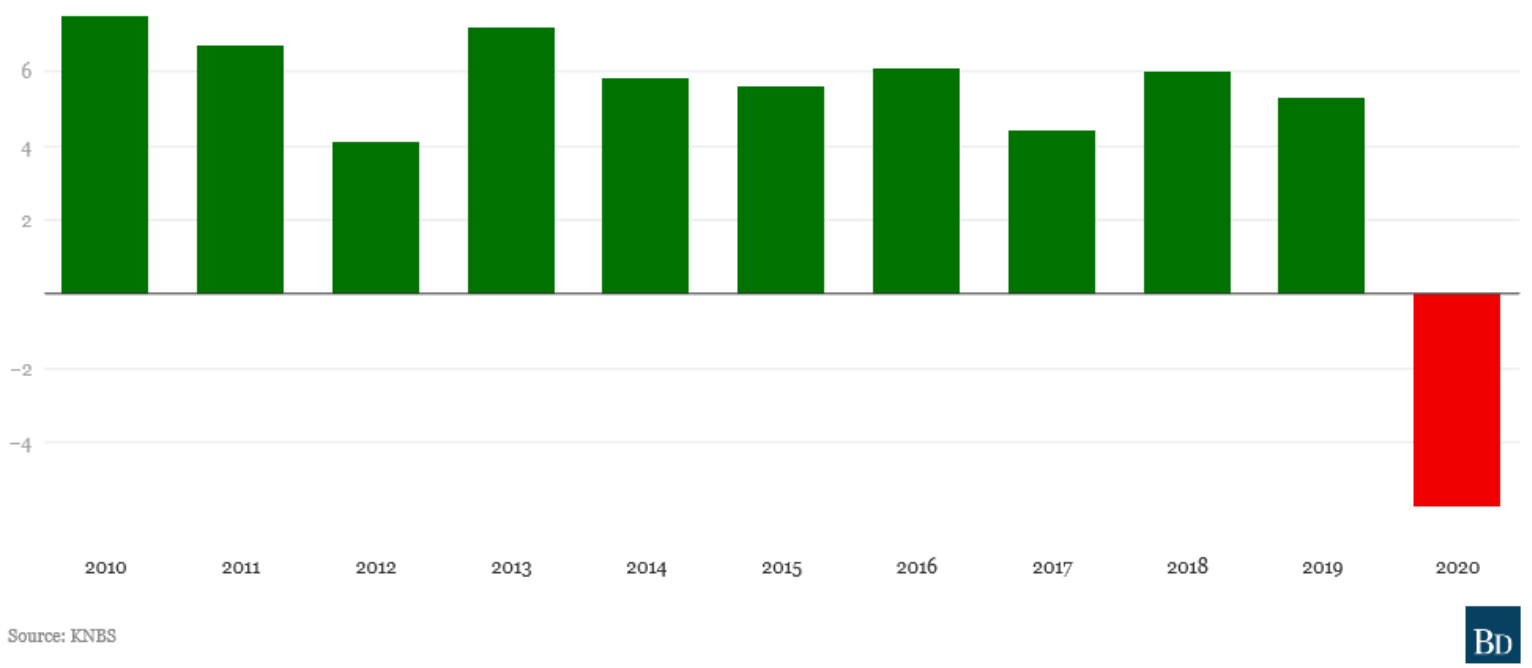

Figure 1. GDP growth rate trend

Source: Business Daily, October 21, 2020

It was also noted that the number of business registrations in the second quarter shot up by $95 \%$ compared to the previous year.

"The number of registered businesses went up significantly starting the month of June this year. There may have arisen need for individuals who may have lost their means of earning a living to register a business to engage in some form of entrepreneurial activity for their sustenance," Business Registration Services (BRS) Director-General Kenneth Gathuma told the Business Daily,BD, (Business Daily, October 21, 2020).

The spike in registration, more so single-owned ventures and small partnerships is a clear indicator that people displaced by the Covid-related measures that led to pay-cuts and mass lay-offs were seeking survival through migration to self-employment or migration from one sector of self-employment to another. This further builds the case for the informal sector as a buffer and fallback for all people when incomes from the formal sector are threatened or ceased. The hasty entry into small business, often without training or guidance, soon contributes to closure of these businesses too.

\section{Business and private companies registration}

Businesses registered in the three months to Sep jumped 95\% compared to same period in 2019

Business Private

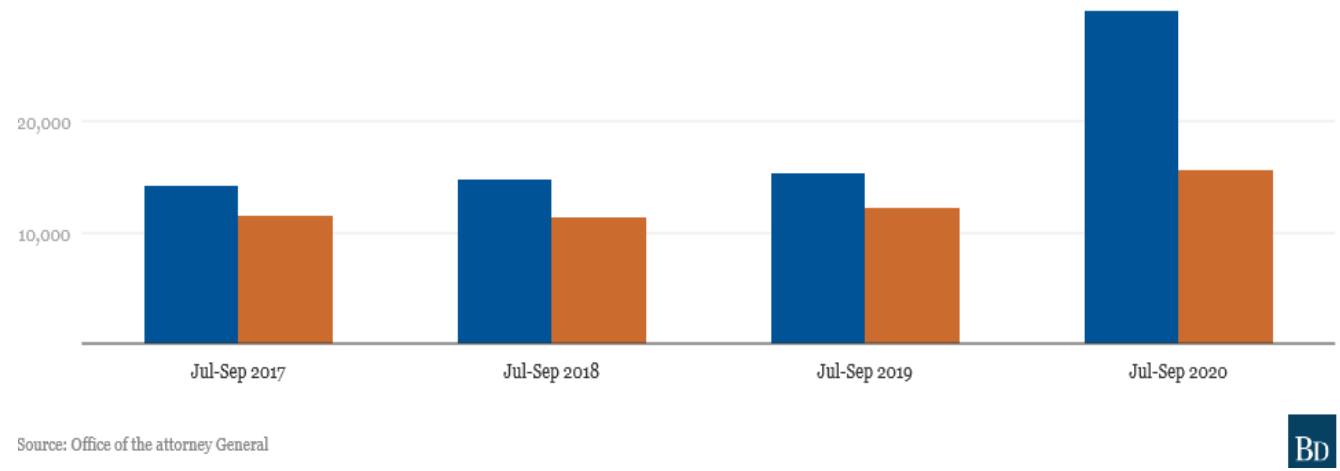

Figure 2. New Business Registrations

Source: Business Daily, October 21, 2020 
MicroSave Consulting, MSC (2020), carried out a research to assess the impact of COVID-19 on MSMEs in Nairobi and Mombasa across urban, semi-urban and rural locations. Quantitative aspects of 103 respondents and qualitative aspects of 15 respondents were analyzed. Among the findings were that micro businesses, most of which are women owned and operate within monthly incomes of USD100-200, had in an effort to survive, reduced expenses even on essential items, quantity and choice of food included. This aggravates the situation for women owned MSMEs, as they tend to be concentrated on low end segments with minimal or no savings (World Bank, 2020).

Women-owned ventures, nevertheless, are predominantly vulnerable to shocks, because they are disproportionately concentrated in informal, low-paying sectors, and also lack elementary formal social defense that would cushion against economic distress. Gradually and as governments started reopening the economies, the tone changed from "stay home" to "stay safe" (Wang, 2020). Most MSMEs are still grappling under the weight of the resulting dilemmas - safety on the one hand, and the need to reopen and safely take the business across the bridge on the other hand. Women -owned MSMEs need help with how to manage the unprecedented pressures, manage the risks and survive beyond the pandemic (World Bank, 2020).

Kenya Association of Manufacturers, (KAM, 2020) conducted a survey among its membership, to establish the effect of covid-related restrictions on the businesses specifically on labor concerns, financial limitations, production and operational challenges. Findings were that 91 percent of non-essential goods manufacturers had recorded a substantial decline in demand compared to 74 percent of essential goods manufacturers. 42 percent were operating at below half their production capacity and 76 percent had challenges in sourcing for raw materials locally and abroad. 79 percent experienced cash flow challenges while 86 percent of manufacturing MSMEs could not meet their financial obligations.

\subsubsection{Rescuing the Women Owned Enterprises}

The Government of Kenya rolled out stimulus packages consisting tax relief and reduction of value added tax to help cushion against the effects of the pandemic (Central Bank of Kenya, 2020). Women entrepreneurs could not benefit from these measures as the incentives broadly benefited the employed people. The formal and more established firms could afford the luxury of rotational working schedules in a bid to social distance, increasing online presence and acceptance of cash-less means of payments as part of safety measures fronted by the Governments through Ministries of Health (McKinsey \& Company, 2020). There is need, therefore, for more targeted policy intervention to help resuscitate the women owned ventures in Kenya.

To summarize the current challenges and opportunities for women owned businesses in Kenya, the Kenya Association of Manufacturers partnered with International Centre for Research in Women (ICRW) to research on Women in Manufacturing in Kenya, and highlighted these as below across all levels (Mugyenyi, Nduta, Ajema, Afifu, Wanjohi, Bomett, Mutuku, \& Yegon, 2020).

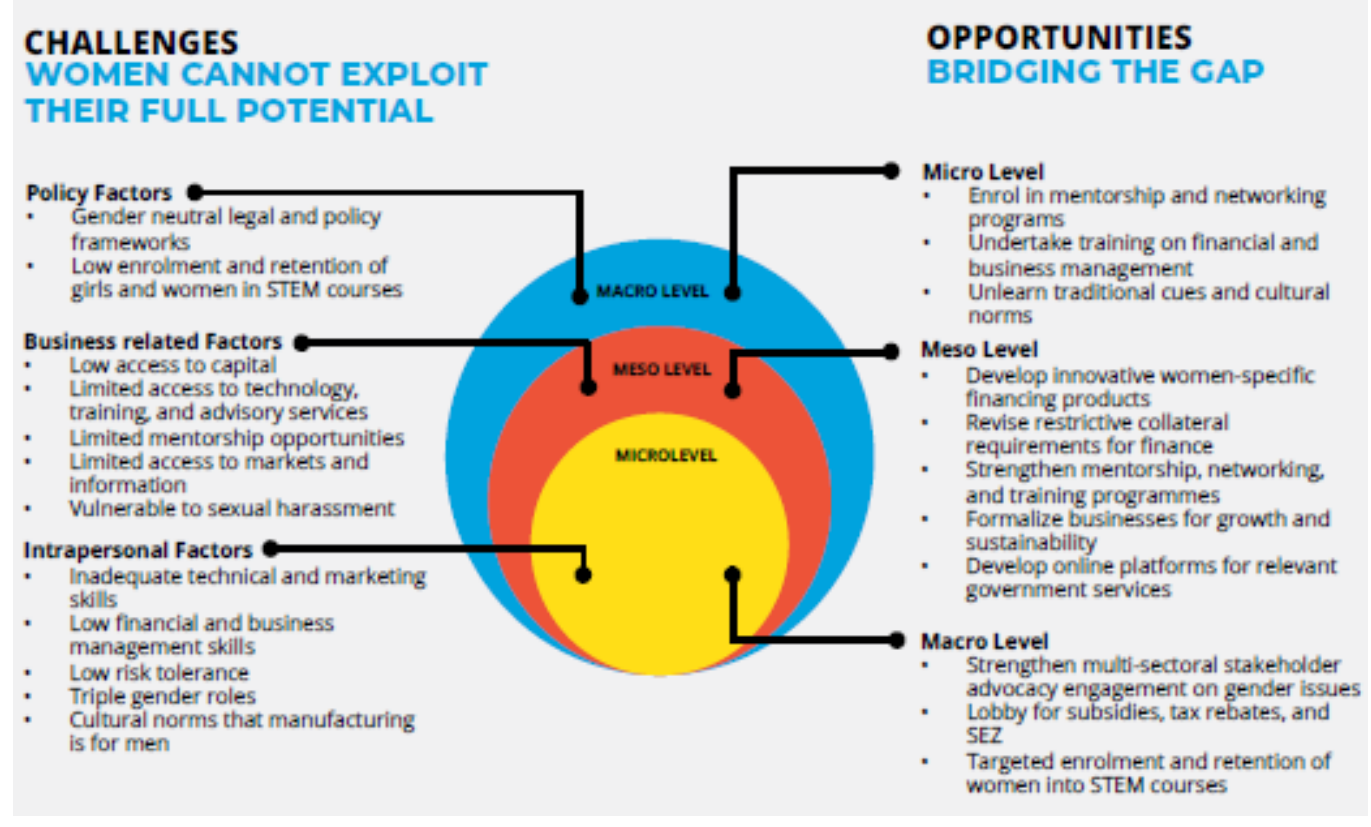

Figure 3. Challenges and Opportunities for Women owned businesses in Kenya

Source: Mugyenyi et. al, 2020. Women in Manufacturing sector in Kenya 
According to the United Nations (2020), COVID-19 impacts on women in two major ways namely the direct and indirect effects of the illness, and the aversion behavior of people that results from fear of contracting the virus. Women owned businesses in Kenya have suffered both aspects; these factors have dented turnover and placed substantial liquidity pressures to cover utility and supplier bills as well as employee salaries.

Due to the resulting uncertainty, most women groups, namely 'Chamas', which ordinarily provide a solid peer social support and business financing, had suspended or ceased operations as most members lost their incomes, affecting regular savings and credit dealings. Member meetings were disrupted due to social distancing and lockdowns too. More female-owned (80\%) compared to male-owned (67.6\%) businesses faced a significant reduction in volume of supplies, with women enterprises reporting an average decline of 50\% in supply volumes in comparison to their male counterparts who experienced an average reduction of $30 \%$.

Based on the above studies, the researcher identified gaps and room for further research into this very promising area; namely the performance of women owned MSMEs during the pandemic. The study thus seeks to bridge the gaps identified and help contribute to existing knowledge on the performance on women owned MSMEs.

Based on the study objective, the hypothesis of the study was:

COVID19 pandemic has no significant effect on the performance of Women Owned Micro, Small, and Medium Enterprises in Kenya.

\section{Research Methodology}

This being a desktop study, the researchers reviewed secondary data through expansive review of available literature, scholarly articles, policy documents, and relevant stakeholder reports. According to Boslaugh (2007), secondary data seeks to study data collected by another party. Vartanian (2010), further posits that secondary data refers to data that was previously collected and which is then considered for new investigations other than the original intention.

Owing to the uncertainty and other effects of this novel virus, use of secondary data was the fastest, most reliable way to gain familiarity on the effects of this new phenomenon as well as acquire new insights into it, so as to inform a more precise problem and facilitate further research. Secondary data was collected from various sources bearing current information about the performance of MSMEs during the global COVID19 pandemic; more so women owned MSMEs.

Martins, da Cunha, and Serra, (2018) strongly recommend secondary data particularly for research areas that have potential for future research and development; effect of covid19 on MSMEs is one such area. They further recommend use of data from reliable sources such as government agencies, international agencies e.g. United Nations, and private entities and agencies e.g. World Bank. Any problems relating to data collection be they errors or

Chivaka (2018) argues that researchers benefit much from usage of secondary data; more so during such difficult times when there is shortage of research funding. This being a novel virus, the precise impact of the pandemic will likely be realized after the pandemic (World Bank, 2020). The secondary data available, therefore, is as the time of writing; August 2020, during which the effects of the pandemic were still being felt by MSMEs and economies alike.

\section{Findings and Discussion}

The role of the female entrepreneur in growth leadership, innovation, generation of employment opportunities, productivity and formation of new industries is evident and could never be downplayed (Nxopo, 2014). The pandemic amplifies its effects through exacerbation of pre-existing inequalities, while deepening the social, political and economic vulnerabilities. There is, therefore, need for further research on the development of women entrepreneurs across all levels of the economy, more so during and post crises such as this pandemic.

The study applied a multidisciplinary based approach to advance the knowledge among stakeholders on strategies and measures that can be put in place to rescue, stabilize, restore and grow women owned micro, small and medium businesses in Kenya and the world at large. A sizeable number of businesses, due to their small size and limited resources, do not cross over to the post-crisis phase (Samantha, 2018). This is evident from the varied studies reviewed, as the findings are mirrored regardless of the economic status of the country (Wenham et.al, 2020; World Bank, 2020; United Nations, 2020). Previous studies, experience of the Ebola virus crises and emerging data reveal that the impact of COVID-19 global economic downturn will result in a prolonged depression in women's incomes and labor force participation, with compounded impact for women already impoverished (Sochas et. al, 2017).

For women who, through their efforts and economic activities had recently escaped dire poverty, the vulnerability and likelihood to slump back is almost certain. In the words of Albert Einstein, "in the midst of every crisis lies great opportunity." Women owned business must therefore be empowered towards 'transiliency'; ability to remain resilient amid radical transformation, (Craighead et. al., 2020). According to the United Nations (2020), COVID-19 impacts on women in two major ways namely the direct and indirect effects of the illness. This therefore implies that women owned 
MSMEs are likely to be double impacted, hence the need to keenly study the impact on them as a key element towards recovery and preparedness for future crisis.

It has also emerged that most enterprises worldwide were not prepared to handle the effects of the pandemic. Given that natural calamities have often forced national and global economies into depression, there is great need for advance planning as well as disaster preparedness not only for governments but for the business enterprises too. Between 1998 and 2017 , the number of natural calamities has massively shot up, during which a sum of $\$ 2.9$ trillion direct economic losses have been posted by affected countries (World Trade Organization, 2019; Shafi et. al., 2020). Businesses must therefore invest in capacity building for disaster management strategies that will empower them to handle similar eventualities in future. (Gittell, Cameron, Lim, Rivas, 2006; Prasad, Su, Altay, \& Tata, 2015)

Scholars too, must rethink their role in carrying out impactful research and subsequently catalyzing recovery among informal businesses before, during and post-pandemics. It is at such moments that all entrepreneurial scholars and researchers should be facilitated to research on the current state of MSMEs, how those that are afloat are managing, and what can the struggling ventures abandon or embrace in order to improve their odds of survival. Such comparative and cross functional studies across segments, sectors and economies can only be fully realized with the help of scholars who often have no partiality or conflicting interests.

\section{Conclusion and Policy Recommendation}

\subsection{Conclusion}

A pandemic magnifies and deepens all existing disparities, which in turn outline who is affected, the severity and depth of the impact, and the commensurate containment measures required. The social and economic impacts of the COVID-19 pandemic have dented the women owned small and medium enterprises in a way that, if left to its natural curve, would take many years to restore to the pre-pandemic position.

Given all the above factors and the complexity of their interplay, it is evident that the COVID-19 pandemic is likely to have a disproportionate impact on women owned businesses more than male-owned businesses in Kenya, as in many other developing economies. This unparalleled crisis, therefore, calls for concerted efforts and policies by all stakeholders, towards remediation of the vulnerable sectors; key among them being women owned MSMEs.

\subsection{Policy Implications}

The COVID-19 global crisis has yet again reminded the world that inequalities exist in the business world, and that the stability of the world's formal economies, the maintenance of our day to day lives and the success of societal units are built on the obscure and unpaid input of women and girls. Boosting the women owned MSMEs, therefore, is an investment in ourselves, and the resultant success is a win-win situation for all.

The study reveals that most MSMEs are severely affected in both income and employment, necessitating strategic restructuring to lessen the economic load. Without government support, these ventures cannot endure the calamity. The governments must, therefore, support these MSMEs in matters income and employment. Further, deliberate efforts to build resilience capability and social support networks are now critical as the only effective business strategies in times of crisis. All businesses must now include a crisis lens as they draw their strategic plans for the coming years. Similarly, small ventures must be facilitated to consider such eventualities in their planning.

Effective crisis management demands that policy actions must include the health and safety of employees, economic stimulation incentives, support in income and employment, and special considerations for marginalized and special groups. It is evident that women owned businesses will be the hardest hit by the impacts of this pandemic. While the Government of Kenya has put in place stimulus packages to help cushion businesses against the adverse effects of COVID-19 pandemic, and the measures indeed appear urgent, the policymakers must strive not to lose the gender perspective in the quest to implement them. Every policy response, therefore, must recognize this and give it a central focus if its impact is to be felt.

Towards Financial assistance to MSMEs, there is need for facilitation of additional and tailor-made lending facilities with reduced interest rates. Though often small in size, women owned ventures exhibit promise to become the backbone of recovery in communities and the country at large Offering moratoriums and restructuring of loan repayments to ease the burden will therefore go a long way in supporting vulnerable women owned MSMEs. Similar policies have been implemented by central banks in economies such as Australia, Canada, New Zealand, U.K. and the U.S.; Italy even extended timelines for repayment of mortgage facilities.

Given that female owned businesses in the informal and service sectors are much more likely to withdraw from the market due to the combined factors brought about by the contagion, there is need for segment specific stimulus packages that target women-owned MSMEs. Both short-term and long-term interventions must therefore 
ensure that women owned businesses get the much-needed boost that will help them stabilize, and create ripple effects of stability in families, communities, counties and the country at large.

\subsection{Limitation and Future Research}

This study reveals glaring gaps in the study and facilitation of recovery of women owned MSMEs during and after the pandemic. The study therefore proposes a deeper multi-disciplinary approach towards finding workable solutions for women owned MSMEs to recover and grow amid and beyond the pandemic.

This is a novel virus; hence it is a developing research area both in the direct and indirect impacts on lives and livelihoods. The precise effects and impact of the pandemic on businesses and economies are yet to be fully appreciated (World Bank, 2020).

This being a desk study, secondary data was used. Secondary data has been known to have weaknesses. Bickman and Rog (1998) argued that the problem with secondary data is that it is data collected by a third party hence the researcher may not have control of the data collection process. For this reason, there may be need to verify the findings using primary data collected by the researcher. This can be done through further research more so after the pandemic, so as to establish the precise effects of the pandemic.

\section{References}

Anyanga, S. O., \& Nyamita, M. O. (2016). The Major Growth Strategies Adopted by Small and Medium Enterprises in Kenya. A Case of Kisumu County. International Journal of Advanced and Multidisciplinary Social Science, 2(1), $11-26$.

Asgary, A., Ozdemir, A. I., \& Özyürek, H. (2020). Small and Medium Enterprises and Global Risks: Evidence from Manufacturing SMEs in Turkey. Int J Disaster Risk Sci, 11, 59-73. https://doi.org/10.1007/s13753-020-00247-0

Bandiera, O., Buehren, N., Goldstein, M., Rasul, I., \& Smurra, A. (2019). The Economic Lives of Young Women in the Time of Ebola: Lessons from an Empowerment Program. Policy Research Working Paper 8760. https://doi.org/10.1596/1813-9450-8760

Bartika, A. W., Bertrandb, M., Cullenc, Z., Glaeserd, E. L., Lucac, M., \& Stanton, C. (2020). The impact of COVID-19 on small business outcomes and expectations. https://doi.org/10.1073/pnas.2006991117

Bickman, L., \& Rog, D. J. (1998). Handbook of Applied Social Research Methods. Sage Publishers, London.

Boniol, M. et al (2019). Gender Equity in the Health Workforce: Analysis of 104 countries. Retrieved from https://apps.who.int/iris/bitstream/handle/10665/311314/WHO-HIS-HWF-Gender-WP1-2019.1-eng.pdf

Business Daily. (2020, October 21). 326 Business registered daily in Covid survival race. Retrieved from https://www.businessdailyafrica.com/bd/economy/326-businesses-registered-dailycovid-survival-race-2485966

Central Bank of Kenya. (2020a). Press Release: Monetary Policy Committee Meeting. Retrieved from https://www.centralbank.go.ke/uploads/mpc_press_release

Central Bank of Kenya. (2020b). Press Release: Monetary Policy Committee Meeting. Retrieved from https://www.centralbank.go.ke/uploads/mpc_press_release

Central Bank of Kenya. (2020c). Press Release: Emergency Measures to Mitigate the Impact on Bank Borrowers from the Coronavirus Pandemic. Retrieved from https://www.centralbank.go.ke/uploads/press_releases/1908080057

Chivaka, R. (2018). Secondary Data Analysis. Retrieved from https://www.researchgate.net/publication/327060808_secondary_data_analysis

Craighead, C. W., Ketchen Jr, D., \& Darby, J. L. (2020). Pandemics and Supply Chain Management Research: Toward a Theoretical Toolbox. Journal of The Decision Sciences institute. https://doi.org/10.1111/deci.12468

Dai, R., Hu, J., \& Zhang, X. (2020). The Impact of Coronavirus on China's SMEs: Findings from the Enterprise Survey for Innovation and Entrepreneurship in China. Retrieved from

https://www.cgdev.org/publication/impact-coronavirus-chinas-smes-findings-from-esiec

Dalberg. (2020). Applying a gender lens to post-Covid economic recoveries: a spotlight on women-led businesses in Africa.

Dzisi, S., \& Ofosu, D. (2014). Marketing Strategies and the Performance of SMEs in Ghana. European Journal of Business and Management, 6(5), 102-111.

Evans, D. (2020). How Will COVID-19 Affect Women and Girls in Low- and Middle-Income Countries? Retrieved from https://www.cgdev.org/blog/how-will-covid-19-affect-women-and-girls-low-and-middle-incomecountries 
Evans, D., \& Over, M., (2020). The Economic Impact of COVID-19 in Low-and Middle-Income Countries. Retrieved from https://www.cgdev.org/blog/economic-impact-covid-19-low-and-middle-income-countries

FAO. (2011). The role of women in agriculture. ESA Working Paper No. 11-02. Food and Agriculture Organization of the United Nations, Rome, Italy.

Gilbert, M., Pullano, G., Pinotti, F., Valdano, E., Poletto, C., Boëlle, P. Y., ... Colizza, V. (2020). Preparedness and vulnerability of African countries against importations of COVID-19: a modelling study. Lancet (London, England), 395(10227), 871-877. https://doi.org/10.1016/S0140-6736(20)30411-6

Gitonga, A. (2020). Fresh produce exports dip 46pc on European markets lockdown. Retrieved from https://www.standardmedia.co.ke/business/article/2001365140/fresh-produce-exports-drop-46per-cent-due-to-a-loc kdown-in-europe

Gittell, J. H., Cameron, K., Lim, S., \& Rivas, V. (2006). Relationships, layoffs, and organizational resilience: Airline industry responses to September 11. The Journal of Applied Behavioral Science, 42(3), 300-329. https://doi.org/10.1177/0021886306286466

Horowit, J. (2020). The global coronavirus recession is beginning. CNN. Media report. Retrieved from https://edition.cnn.com/2020/03/16/economy/global-recession-coronavirus/index.html

International Development Research Centre, IDRC, 2016. Retrieved from https://idl-bnc-idrc.dspacedirect.org/bitstream/handle/10625/56366/IDL-56366.pdf?sequence=2\&isAllowed=y

International Labour Organization, 2020. COVID-19 and the world of work: Updated estimates and analysis. ILO Monitor (2nd ed.).

Kawira, K. D., Mukulu, E., \& Odhiambo, R. (2019). Effect of Digital Marketing on the Performance of MSMES in Kenya, Journal of Marketing \&Communication, 2(1), 1-23.

Kenya Private Sector Alliance (KEPSA) (2020b). Agriculture Sector Business Response to CODIV-19, KEPSA, Nairobi.

Kenya Private Sector Alliance. (KEPSA). (2020a). Business Perspectives on the Impact of the Coronavirus on Kenya's Economy, KEPSA, Nairobi.

KIPPRA. (2013). Kenya Economic Report. Nairobi: Government Printer.

KNBS, (2016). Micro, Small and Medium Establishments (MSME survey Report).Nairobi: Government Printer.

KNBS, (2018). Labor Force Basic Report.

KNBS, (2020a). Quarterly Gross Domestic Product Report - Second Quarter.

KNBS, (2020b). Economic Survey 2020KNBS, (February 2020). Quarterly Labour Force Survey, October to December 2019. Retrieved from https://www.knbs.or.ke/?wpdmpro=quarterly- labour-force-report-forth-quarter-2019

Korkoya, D., T., Jr., \& Wreh, F., F., (2015). Ebola Impact Revealed: An Assessment of the Differing Impact of the Outbreak on Women and Men in Liberia. Retrieved from https://oxfamilibrary.openrepository.com/bitstream/handle

Lakuma, C. P., \& Sunday, N. (2020). Impact of COVID-19 on Micro, Small and Medium Enterprises in Uganda. Retrieved from

https://www.brookings.edu/blog/africa-in-focus/2020/05/19/impact-of-covid-19-on-micro-small-and-medium-busi nesses-in-uganda/

Larry, E. L. (2020). Prepare for the coronavirus global recession. The Guardian. Media report. Retrieved from https://www.theguardian.com/business/2020/mar/15/prepare-for-the-coronavirusglobal-recession

Martins, F., da Cunha, J., \& Serra, F. (2018). Secondary Data in Research - Uses and Opportunities. Iberoamerican Journal of Strategic Management (IJSM), 17(4), 01-04. https://doi.org/10.5585/ijsm.v17i4.2723

McKibbin, W. J., \& Fernando, R. (2020). The Global Macroeconomic Impacts of COVID-19: Seven Scenarios. https://doi.org/10.2139/ssrn.3547729

MicroSave Consulting. (2020). Retrieved from https://www.microsave.net/wp-content/uploads/2020/07/Impact-of-COVID-19-pandemic-on-MSMEs-Kenya.pdf

Miles, M. P., Lehman, K., \& Fillis, I. (2017). The museum of old and new art: Leveragingentr epreneurial marketing to create a unique arts and vacation venture. Journal of Vacation Marketing, 23(1), 85-96. https://doi.org/10.1177/1356766716634153

Ministry of Health. (2014). Health Sector Human Resources Strategy 2014 - 2018. Retrieved from http://www.health.go.ke/wpcontent/uploads/2016/04/Kenya-HRH-Strategy-2014-2018.pdf 
Mugyenyi C., Nduta N., Ajema C., Afifu C., Wanjohi J., Bomett M., Mutuku C., \& Yegon E. (2020). Women in Manufacturing: Mainstreaming Gender and Inclusion. Nairobi, Kenya. International Center for Research on Women (ICRW) and Kenya Association of Manufacturers (KAM).

Nastopoulos, C. (2020). A Scenario-Based Analysis on the Impact of COVID-19 on the Public Sector, Private Sector, and International Business. (2020). Senior Theses. 379. Retrieved from https://scholarcommons.sc.edu/senior_theses/379

Ndiaye, N., Razak, L. A., Nagayev, R., \& Ng, A. (2018). Demystifying small and medium enterprises' (SMEs) performance in emerging and developing economies. Borsa Istanbul Review, 18(4), 269-281. https://doi.org/10.1016/j.bir.2018.04.003

Neneh, N. B., \& Zyl, Z. H. (2012). Achieving optimal business performance through business practices: evidence from SMEs in selected areas in South Africa. Southern African Business Review, 16(3), 118-144.

OECD. (2020). OECD Interim Economic Outlook, March 2020. Retrieved from https://www.oecd.org/economic-outlook

Otini, R. (2020). NSE suspends trading as coronavirus fears wipe out Sh240 billion. Retrieved from https://www.standardmedia.co.ke/business/article/2001364144/nse-suspends-trading-as-coronavirus-fears-wipe-out -sh240-billion

Oxfam. (2019). Gendered Patterns of Unpaid Care and Domestic Work in the Urban Informal Settlements of Nairobi, Kenya, Findings from a Household Care Survey 2019. Retrieved from https://kenya.oxfam.org/latest/policy-paper/gendered-patterns-unpaid-care-and-domestic-work-urban-informal-sett lements

Prasad, S., Su, H. C., Altay, N., \& Tata, J. (2015). Building disaster-resilient micro enterprises in the developing world. Disasters, 39(3), 447-466. https://doi.org/10.1111/disa.12117

Rapoza, K., (2020). Watch out for china buying spree, NATO warns. Forbes (2020) Retrieved from https://www.forbes.com/sites/kenrapoza/2020/04/18/watch-out-for-china-buying-spree-nato-warns/\#623eada31758

Samantha, G. (2018). The impact of natural disasters on micro, small and medium enterprises (MSMEs): A case study on 2016 flood event in western Sri Lanka. Procedia Engineering, 212(2018), 744-751. https://doi.org/10.1016/j.proeng.2018.01.096

Shafi, M., Liu, J., \& Ren, W. (2020). Impact of COVID-19 pandemic on micro, small, and medium-sized Enterprises operating in Pakistan. Retrieved from https://doi.org/10.1016/j.resglo.2020.100018

Shah, S. S. R. (2020). Impact of COVID-19 on Kenya's Economic Development. Retrieved from https://www.policycenter.ma/opinion/impact-covid-19-kenyas-economic-development\#.XwsLv6Eza1s

Theuri, P. (2020). Traders begin to bear brunt of coronavirus. Retrieved from https://www.standardmedia.co.ke/business/article/2001364260/traders-begin-to-bear-brunt-of-coronavirus

U.N. (2020a). The impact of Covid-19 on women. Retrieved from https://www.un.org/sexualviolenceinconflict/wp-content/uploads/2020/06/report/policy-brief-the-impact-of-covid19-on-women

UNDP. (2020b). Tackling Social Norms: A game changer for gender inequalities. Retrieved from http://hdr.undp.org/en/gsni

UNDP. (2020c). Socio-Economic-Impact-COVID-19-Kenya-Policy-Brief-UNDP-Kenya-April

United Nations Economic Commission For Africa (2020). ECA estimates billions worth of losses in Africa due to COVID-19 impact. Retrieved from

https://www.uneca.org/stories/eca-estimates-billions-worth-losses-africa-due-covid-19-impact

Wang, G. (2020). Stay at Home to Stay Safe: Effectiveness of Stay-at-Home Orders in Containing the COVID-19 Pandemic. https://doi.org/10.2139/ssrn.3581873

Wenham, C., Smith, J., \& Morgan, R. (2020). COVID-19: the gendered impacts of the outbreak. https://doi.org/10.1016/S0140-6736(20)30526-2

WHO. (2007). Addressing sex and gender in epidemic-prone infectious diseases. Retrieved from https://www.who.int/csr/resources/publications/SexGenderInfectDis.pdf

Williams, S., \& Schaefer, A. (2020). Small and medium-sized enterprises and sustainability: Managers' values and engagement with environmental and climate change issues. Business Strategy and the Environment, 22(3), 173-186. https://doi.org/10.1002/bse. 1740 
Women Entrepreneurs Finance Initiative. (2020). Retrieved from

https://we-fi.org/research-and-data-on-the-impact-of-the-coronavirus-on-women-led-smes/

World Bank. (2020). Retrieved from

Supporting-Women-Throughout-the-Coronavirus-Covid-19-Emergency-Response-and-Economic-Recovery

World Health Organization (WHO). (2020). Retrieved June 10, 2020, from https://covid19.who.int/

Worldometer. (2020). https://www.worldometers.info/coronavirus/\#countries

\section{Copyrights}

Copyright for this article is retained by the author(s), with first publication rights granted to the journal.

This is an open-access article distributed under the terms and conditions of the Creative Commons Attribution license which permits unrestricted use, distribution, and reproduction in any medium, provided the original work is properly cited. 